\title{
Nitrogen Management for Improving Root and Shoot Components of Young 'Arbequina' Olives
}

\author{
Daniel Leskovar ${ }^{1}$ \\ Texas A\&M AgriLife Research and Extension Center, Texas A\&M University, \\ Uvalde, TX 78801
}

\section{Yahia A. Othman}

Department of Hoticulture and Crop Science, The University of Jordan, Amman 11942, Jordan; and Texas A\&M AgriLife Research and Extension Center, Texas A\&M University, Uvalde, TX 78801

Additional index words. slow-release fertilizer, ammonium nitrate, stomatal conductance, photosynthesis, root analysis

\begin{abstract}
The impact of nitrogen application on the growth of olive trees has been well studied. However, little is known about the role of levels and forms of $N$ on the development of roots and physiological traits during establishment of young trees. The objective of this 2-year study was to evaluate the influence of $\mathrm{N}$ source and level on shoot morphology (tree height, stem diameter, and branch number) and physiology [leaf area and fresh weight, photosynthesis $\left(P_{n}\right)$, transpiration $(E)$, and stomatal conductance $\left.\left(g_{s}\right)\right]$, root components (length, diameter, surface area, and fork number) and $\mathrm{N}$ content of young olive (Olea europaea cv. Arbequina) cuttings. Three-month-old olive cuttings were planted in 15-L pots filled with a growing substrate composed of peatmoss + bark + sand (2:1:1/by volume) and placed in a screen house. Two $N$ levels, 2.8 and $5.6 \mathrm{~g} /$ tree, and control $(0 \mathrm{~N})$ and four $\mathrm{N}$ sources, calcium nitrate $\left(\mathrm{CN}, 12 \% \mathrm{~N}, 17 \% \mathrm{Ca}^{+2}\right)$, ammonium nitrate $(\mathrm{AN}, 35 \% \mathrm{~N})$, urea $(46 \% \mathrm{~N})$, and the slow-release Osmocote $(\mathrm{OSC}, 18 \% \mathrm{~N}, 6 \% \mathrm{P}$, $12 \% \mathrm{~K})$ were evaluated. Effects of low- $(2.8 \mathrm{~g} /$ tree $)$ and high $N(5.6 \mathrm{~g} /$ tree $)$ levels on shoot components (plant height, diameter, branch number, leaf area, and fresh weight) and gas exchange $\left(\mathrm{P}_{n}, g_{\mathrm{s}}\right.$ and $\left.E\right)$ were similar implying that the low rate of $\mathrm{N}$ was adequate for the establishment of young olive cuttings. Nitrogen sources, particularly AN and $\mathrm{CN}$ had significant effects on shoot and root morphology, physiology, and leaf and root $N$ concentration. In fact, $\mathrm{AN}$ and $\mathrm{CN}$ were the best fertilizer sources for olive transplants in term of root and shoot growth. Overall, $2.8 \mathrm{~g} /$ tree $\mathrm{N}$ level and $\mathrm{AN}$ or $\mathrm{CN}$ sources were the best treatments for newly established olive 'Arbequina' trees. Root components treated with high $\mathrm{N}$ rate $(5.6 \mathrm{~g} /$ tree $\mathrm{N})$ using the slow-release fertilizer (OSC) was similar to those treated with the low AN rate (2.8 g/tree $\mathrm{N})$. Therefore, for nursery containerized olive trees of 'Arbequina' or other cultivars with comparable growth rates, we recommend to apply the $\mathrm{CN}$ or AN source at $2.8 \mathrm{~g}$ /tree $\mathrm{N}$ or the controlled-released fertilizer OSC at $5.6 \mathrm{~g} /$ tree $\mathrm{N}$.
\end{abstract}

Plant nutritional status, specifically nitrogen $(\mathrm{N})$, plays key roles in olive growth and productivity (Rodrigues et al., 2011a). Plants develop unique physiological and diverse developmental mechanisms that control $\mathrm{N}$ root uptake capacity, adapting to fluctuating $\mathrm{N}$ resource availability (Nacry et al., 2013). Because of the transient nature of $\mathrm{N}$ in the soil/plant system, Rodrigues et al. (2012) recommends that $\mathrm{N}$ be applied every year to increase the nutrient-use efficiency of olive

Received for publication 17 July 2018. Accepted for publication 13 Sept. 2018.

This work was supported by partial funds from the Texas Department of Agriculture, Specialty Crop Block Program. We also thank our staff Manuel Figueroa-Pagan, Juan Esquivel, Carrie Hensarling, Dr. Madhumita Joshi, and Audra Elrod for their assistance in the laboratory and field.

${ }^{1}$ Corresponding author. E-mail: d-leskovar@tamu. edu. trees. However, the requirement of optimal $\mathrm{N}$ concentration in leaves and roots is controversial. For example, in young olive trees 'Meski' and 'Koroneiki' N deficiency (no N applied) reduced net $\mathrm{CO}_{2}$ assimilation rate but did not significantly change the maximum quantum efficiency of PSII photochemistry (Boussadia et al., 2015). Although N-deficient olive seedling had higher levels of starch, mannitol, sucrose, and glucose the same cuttings had lower leaf $\mathrm{N}$ and chlorophyll a content, leaf dry weight, and photosynthetic capacity (Boussadia et al., 2010). Troyanos and Roukounaki (2011) found that olive cuttings subjected to high levels of $\mathrm{N}(6.25 \mathrm{~g} /$ tree $\mathrm{N})$ had higher leaf dry weight and shorter root system compared with control-untreated cuttings.

The optimal $\mathrm{N}$ content is known as the minimum shoot $\mathrm{N}$ content required by a crop to reach maximum growth (Boussadia et al., 2015). Developmental root components including root hairs and lateral roots are par- ticularly highly sensitive to the internal and external concentration of nutrients such as $\mathrm{N}$ and phosphorus (P) (López-Bucio et al., 2003). In olive, it has been shown that the leaf $\mathrm{N}$ concentration greater than $1.7 \%$ (dry weight) has negative effects on flower and oil quality (Molina-Soria and FernándezEscobar, 2010). Olive cuttings fertilized with $0.75 \mathrm{~g} \mathrm{~N}$ per pot had higher shoot growth than those that received $2 \mathrm{~g} \mathrm{~N}$ (Fernández-Escobar et al., 2004). Interestingly, elongation of fine cuttings roots of cv. Koroneiki was enhanced under severe $\mathrm{N}$ deprivation (Boussadia et al., 2010).

In addition to $\mathrm{N}$ level, $\mathrm{N}$ form can significantly affect root and shoot growth and development ( $\mathrm{Lu}$ et al., 2009; Takács and Técsi, 1992). Moreover, $\mathrm{N}$ form and nitrate $\left(\mathrm{NO}_{3}{ }^{-}\right)$/ammonium $\left(\mathrm{NH}_{4}{ }^{+}\right)$ratio play a key role in shoot and root development and the ultrastructure of chloroplasts (López-Bucio et al., 2003; Takács and Técsi, 1992). Nitrogen is available for plants in either organic (free amino acids) or inorganic $\left(\mathrm{NO}_{3}{ }^{-}\right.$and $\mathrm{NH}_{4}^{+}$) forms (Kiba et al., 2011), with $\mathrm{NO}_{3}$ being the main source of inorganic $\mathrm{N}$ (Andrews, 1986). The reduction rate of $\mathrm{NO}_{3}{ }^{-}$to ammonia in plant shoot to fulfill its essential functions as a plant nutrient depends on the level of nitrate supply, cultivar, and growth stage (Bouranis et al., 2004). Olive cuttings that received $16 \mathrm{~mm}$ urea-N had better growth compared with those that received either $\mathrm{NO}_{3}{ }^{-}$, or $\mathrm{NH}_{4}{ }^{+}$, or the combination of $\mathrm{NH}_{4}{ }^{+}+\mathrm{NO}_{3}{ }^{-}$. However, at lower $\mathrm{N}$ levels using ( 1 or $8 \mathrm{~mm}$ ), higher plant growth was noticed when they were fertilized with $\mathrm{NO}_{3}{ }^{-}-\mathrm{N}$ (Tsabarducas et al., 2017).

In agricultural soils, low $\mathrm{N}$ retrieval by plants increases the total $\mathrm{N}$ losses from the field, triggering undesirable effects on the environment (Fernández-Escobar et al., 2004). A study by Fernández-Escobar et al. (2012) found that, when $\mathrm{N}$ was applied annually to fertile olive orchards, $\mathrm{N}$ net mineralization was decreased and $\mathrm{N}$ net immobilization into soil organic matter increased. Consequently, $\mathrm{N}$ leaching increased because of excess of $\mathrm{N}$ applied, causing a disruption of the $\mathrm{N}$ balance in the soil and environmental damage. Slowrelease $\mathrm{N}$ fertilizers provide a slow supply of $\mathrm{N}$ to plants for a longer period as compared with traditional $\mathrm{N}$ fertilizers. As a result, $\mathrm{N}$ use efficiency increased and the total $\mathrm{N}$ losses by leaching decreased (FernándezEscobar et al., 2004). Studies on the effect of $\mathrm{N}$ application on olive growth have been common recently (Troyanos and Roukounaki, 2011; Tsabarducas et al., 2017). It has been claimed that $\mathrm{N}$ fertilizer is not essential when olive orchard soils are fertile and leaf $\mathrm{N}$ content ranges from $1.22 \%$ to $1.35 \% \mathrm{~N}$ (\% leaf dry matter) (Fernández-Escobar et al., 2012; Molina-Soria and Fernández-Escobar, 2010). However, few have included root components (length, diameter, surface area, and fork number) and leaf gas exchange analysis as an aid to determine the optimal $\mathrm{N}$ level for olive growth, specifically at early growth stages. The influence of $\mathrm{N}$ source on young olive plants is also not well known, especially, 
those from slow-release N. We hypothesize that low $\mathrm{N}$ levels can enhance root components and shoot growth. We also hypothesize that $\mathrm{N}$ form $\left(\mathrm{NH}_{4}^{+}\right.$or $\left.\mathrm{NO}_{3}^{-}\right)$has differential effects on shoot and root growth. The objective of this research was to evaluate the influence of $\mathrm{N}$ source and level on shoot morphology and physiology, root component and plant $\mathrm{N}$ content of young olive cuttings cv. Arbequina.

\section{Material and Methods}

Plant material and experiment setup. A 2year study was established in pots under a screen house to evaluate the impact of $\mathrm{N}$ rate and fertilizer source based on different proportions of $\mathrm{N}$ sources $\mathrm{NH}_{4}{ }^{+}, \mathrm{NO}_{3}{ }^{-}$and mix of $\mathrm{NH}_{4}{ }^{+}$and $\mathrm{NO}_{3}{ }^{-}$. The research was carried out during the 2015-16 period at the Texas A\&M AgriLife Research and Extension Center, Uvalde, TX (lat. 99 $45^{\prime} 21.6^{\prime \prime} \mathrm{W}$, long. $\left.29^{\circ} 12^{\prime} 57.6^{\prime \prime} \mathrm{N}\right)$. Three-month old olive $(O$. europaea cv. Arbequina) cuttings were planted on 13 May 2015 in 15 L pots (diameter $30 \mathrm{~cm}$ ) filled with growing substrate composed of peatmoss + bark + sand (2:1:1/ by volume). The chemical composition of the growing media is described in Table 1 . The selected plants were uniform in growth (shoot height, stem diameter, number branches, and leaves). The average plant height for olive cuttings was $70 \mathrm{~cm}$, stem diameter was $0.5 \mathrm{~cm}$, number of leaves was 75 , and branches number was seven. Olive cuttings in pots were placed on a bench table in screen house with fabric mesh $(50 \%$ shade percentage) and left open from the top. Mean temperatures, relative humidity, and light intensity during the study period are given in Fig. 1.

Nitrogen source and rate. During the study period, the following nine treatments were evaluated: control (no N), $\mathrm{NO}_{3}{ }^{-}$source applied as $\mathrm{CN}\left(12 \% \mathrm{~N}, 17 \% \mathrm{Ca}^{+2}\right)$ at 2.8 and $5.6 \mathrm{~g} /$ tree, $\mathrm{NO}_{3}{ }^{-}+\mathrm{NH}_{4}{ }^{+}$applied as $\mathrm{AN}(35 \%$ $\mathrm{N})$ at 2.8 and $5.6 \mathrm{~g} /$ tree, $\mathrm{NH}_{4}{ }^{+}$applied as urea $(46 \% \mathrm{~N})$ at 2.8 and $5.6 \mathrm{~g} /$ tree, and the controlled-release fertilizer OSC: 18-6-12 applied at 2.8 and $5.6 \mathrm{~g} /$ tree. The experiment was designed as a complete randomized block design with four replications containing two plants per replication (eight total per treatment) in the first year and one plant per replication (four total per treatment) in the second year (2016). For each treatment and

Table 1. Growing media chemical analysis at the beginning of the experimental study.

\begin{tabular}{lr}
\hline Variable & Concn. \\
\hline $\mathrm{pH}$ & 5.2 \\
Conductivity $\left(\mu \mathrm{mho} \cdot \mathrm{cm}^{-1}\right)$ & 128.0 \\
Nitrate-N $(\mathrm{ppm})$ & 1.0 \\
Phosphorus $(\mathrm{ppm})$ & 4.7 \\
Potassium $(\mathrm{ppm})$ & 22.7 \\
Calcium $(\mathrm{ppm})$ & 816.0 \\
Magnesium $(\mathrm{ppm})$ & 74.7 \\
Sulfur $(\mathrm{ppm})$ & 7.3 \\
Sodium $(\mathrm{ppm})$ & 1.7 \\
Organic matter $(\%)$ & 8.4 \\
\hline
\end{tabular}

year, four young trees were used for destructive measurements (root and leaf analysis) each year. For each year, the total OSC fertilizer was applied once at the beginning of the growing season, whereas the other three sources (CN, AN, and urea) were applied weekly as a drench treatment at a rate of 120 $\mathrm{mL}$ per pot over a 20 -week period every year. To balance the additional nutrient content $\left(\mathrm{Ca}^{+2}, \mathrm{P}\right.$, and $\left.\mathrm{K}\right)$ provided in the $\mathrm{CN}\left(\mathrm{Ca}^{+2}\right)$ and $\mathrm{OSC}(\mathrm{P}, \mathrm{K})$ treatments were compensated with equivalent amounts of calcium sulfate, rock phosphate, and potash, which were applied once at the time of planting and the beginning of the second year.

Growth and physiology measurements. In both seasons, leaf gas exchange $\left(\mathrm{P}_{\mathrm{n}}, E\right.$, and $g_{\mathrm{s}}$ ) were measured 15 weeks after the $\mathrm{N}$ application in each year. Gas exchange measurements were conducted between 1100 and $1300 \mathrm{HR}$ from two fully expanded leaves. Gas exchange measurements were determined using a portable photosynthesis system (LI6400XT; LI-COR, Lincoln, NE) and using the procedures of Othman et al. (2014). At the end of each growing season ( 20 weeks after $\mathrm{N}$ application), plant size (height and width) was measured and then four olive cuttings from each treatment were harvested and divided into shoot and roots, and then, the number of branches, stem diameter, leaf fresh weight, leaf area, and root components were determined. The leaf area was measured using a leaf area meter (LI-3100C Area Meter; LI-COR). The root components (length, surface area, diameter, volume, and fork number) were measured using a WinRHIZO image analysis system (V5.0; Regent Instruments, Quebec, Canada). Leaf and root $\mathrm{N} \%$ was determined using the procedures of Al-Ajlouni et al. (2017). Leaves and root samples were collected, oven dried for $3 \mathrm{~d}$ at $65^{\circ} \mathrm{C}$, then, total $\mathrm{N}$ was determined using a discrete analyzer (Easy Chem. Plus; Analytical Technologies, Anagni, Italy).

Statistical analysis. A randomized complete block design with four replications and two factors ( $3 \mathrm{~N}$ levels and $4 \mathrm{~N}$ sources) was used. For the experiment, four replications represented by two trees each in 2015 and one tree each in 2016 were used. The analysis of variance and the least significant deference test $(P=0.05)$ in SAS (Version 9.4 for Windows; SAS Institute, Inc., Cary, NC) were used to identify differences between $\mathrm{N}$ levels, sources, and their interactions.

\section{Results}

Morphology and physiology. During the study period (2015-16), plant morphology (plant height, stem diameter, branch number, leaf area, and leaf fresh and dry weight) and gas exchange $\left(\mathrm{P}_{\mathrm{n}}, g_{\mathrm{s}}\right.$ and $\left.E\right)$ from the 2.8

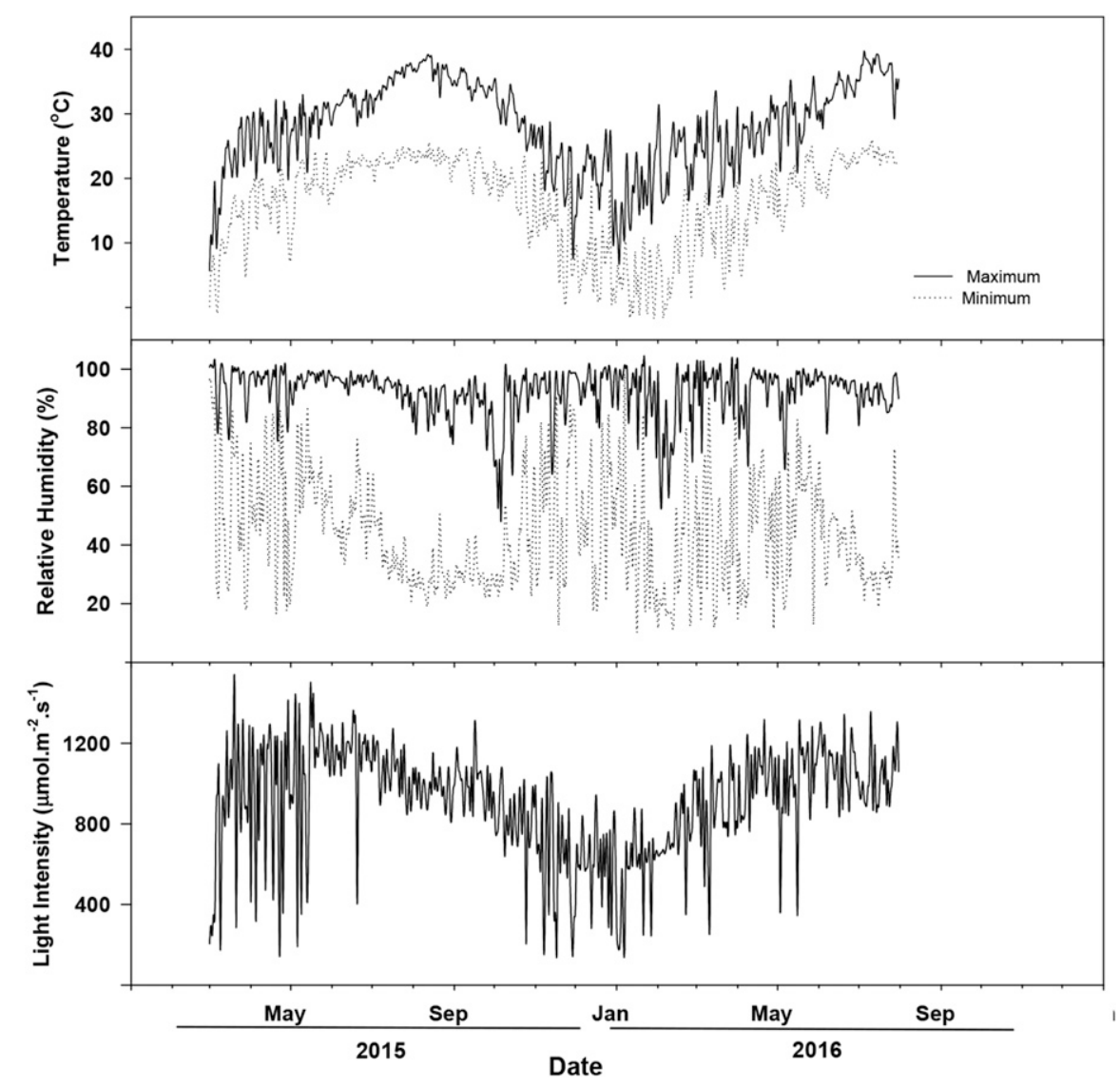

Fig. 1. Mean minimum and maximum temperatures, relative humidity, and light intensity during the study period from the weather station near the net house $(\approx 200 \mathrm{~m})$ at Uvalde, TX. 
$\mathrm{g} /$ tree $\mathrm{N}$ rate were similar to those plants from $5.6 \mathrm{~g} /$ tree $\mathrm{N}$ (Table 2). No significant difference was noticed in $g_{\text {s }}$ and $E$ over the study period across both $\mathrm{N}$ levels $(2.8$ and $5.6 \mathrm{~g} /$ tree ) and $\mathrm{N}$ sources (AN, CN, urea, and OSC). However, in 2015, plants grown with AN fertilizer had higher leaf area and fresh weight than with other $\mathrm{N}$ fertilizer sources. In addition, in $2016 \mathrm{CN}$ had higher plant height, stem diameter, leaf area, and leaf fresh and dry weight than OSC and urea (Table 2). In both years, plant morphological components and $\mathrm{P}_{\mathrm{n}}$ from untreated plants were significantly lower than those with $\mathrm{N}$-treated plants. OSC had higher $\mathrm{P}_{\mathrm{n}}$ rate than urea in 2015, following the same trends, although not significantly in 2016 (Table 2).

Plants fertilized using the high $\mathrm{N}$ rate (5.6 $\mathrm{g} /$ tree N) had higher leaf and root N\% when compared with the low rate $\mathrm{N}(2.8 \mathrm{~g} /$ tree $\mathrm{N})$ and control $(0 \mathrm{~g} /$ tree $\mathrm{N})$ across the study period (2015-16) (Table 3). The leaf N\% was higher than the root $\mathrm{N} \%$ across the $\mathrm{N}$ sources and levels (except for control in 2016). In addition, AN source had higher $\mathrm{N} \%$ than OSC (slow-release fertilizer) in leaf and root across the study period (Table 3 ). Interestingly, overall $\mathrm{CN}$ gave more $\mathrm{NO}_{3}{ }^{-}$in roots and least in leaves, whereas the opposite was found for OSC, with more $\mathrm{NO}_{3}{ }^{-}$in leaves and less in roots. However, leaf $\mathrm{NO}_{3}{ }^{-}$concentration from the $2.8 \mathrm{~g} /$ tree rate was similar to those plants fertilized with $5.6 \mathrm{~g} /$ tree $\mathrm{N}$ (Table 3) with an average of $0.024 \%$ and did not differ significantly from the control.

Root components. Root component analysis of olive transplants revealed significant differences between $\mathrm{N}$ fertilizer sources and levels in both years (Table 4; Fig. 2). In addition, there was a significant $\mathrm{N}$ source and level interactions for root length and root surface area in 2015 and all root components (except root diameter) in 2016 (Table 4; Fig. 2). The $\mathrm{N}$ source and level treatment interactions revealed that, in 2015, root length, surface area, and root volume (Fig. 2) from the control $(0 \mathrm{~g} /$ tree $\mathrm{N})$ plants was significantly higher than low $(2.8 \mathrm{~g} /$ tree $\mathrm{N})$ or high $(5.6 \mathrm{~g} /$ tree $\mathrm{N})$ rates of $\mathrm{AN}$ and OSC. Conversely, in 2016, after 2 years of $\mathrm{N}$ application, both $\mathrm{N}$ sources, AN and OSC, significantly increased root components as compared with control. After 2 years of $\mathrm{N}$ application, the lower rate $(2.8 \mathrm{~g} /$ tree $\mathrm{N})$ of $\mathrm{AN}$ and $\mathrm{CN}$ and the high rate $(5.6 \mathrm{~g} /$ tree $\mathrm{N})$ of $\mathrm{AN}$ and OSC had higher root dry weight, root volume, root surface area, total root length, and fork number than other treatments (Fig. 2).

\section{Discussion}

Morphology and physiology. In this study, plant morphology and leaf gas exchange parameters $\left(\mathrm{P}_{\mathrm{n}}, g_{\mathrm{s}}\right.$ and $\left.E\right)$ from the 2.8 and $5.6 \mathrm{~g} /$ tree $\mathrm{N}$ were statistically similar. It has been shown that morphological traits such as leaf area and leaf dry weight are vulnerable to $\mathrm{N}$ availability (Saidana et al., 2009). A hydroponic study for growth analysis using olive seedlings also confirmed the negative effects of nutritional stresses on dry matter, chlorophyll concentration, and higher stomata resistance (Saidana et al., 2009). Consistent with the reports showing reduced yield and leaf $\mathrm{N}$ content in the orchards receiving no nitrogen (Rodrigues et al., 2011b), in this study the plant morphological components and $\mathrm{P}_{\mathrm{n}}$ from untreated control plants were significantly lower than N-treated plants.

From the substrate data reported in Table 1 , there was $8.4 \%$ of organic matter that can release nutrients over time. In fact, $\mathrm{NO}_{3}{ }^{-}$ content for the growing substrate was $1 \mathrm{mg} \cdot \mathrm{kg}^{-1}$ at the beginning of the experiment. However, the untreated-N control treatment had lower shoot and root growth compared with N-treated trees. Therefore, we believe that the released nutrients (specifically $\mathrm{N}$ ) from the growing substrate had slight effects on the olive trees growth.

The increase in leaf and root $\mathrm{N} \%$ in response to the higher application rate (5.6 $\mathrm{g} /$ tree $\mathrm{N})$ compared with the control $(0 \mathrm{~g} /$ tree $\mathrm{N})$ or lower rate $\mathrm{N}(2.8 \mathrm{~g} /$ tree $\mathrm{N})$ in both years, 2015 and 2016, agrees with the findings by Connell et al. (2002) on 'Mission' table olive. Except for the control in 2016, olive leaves had higher N\% than roots across the $\mathrm{N}$ sources and levels. Fernández-Escobar et al. (2004) concluded that regardless of $\mathrm{N}$ formulation in conventional or slow-release $\mathrm{N}$ fertilizers, $\mathrm{N}$ is accumulated mainly in leaves of the olive transplants. In both growing seasons, the controlled-release fertilizer (OSC) had consistently lower $\mathrm{N} \%$ than the other three $\mathrm{N}$ sources (Table 3). The slow release of $\mathrm{N}$ might be beneficial for young seedlings to avoid potential toxic effect to the root system (Fernández-Escobar et al., 2004) as well as runoff and leaching losses.

A long-term study in Spain by FernándezEscobar et al. (2012) in fertile olive orchard soil (clay loamy to sandy clay soil) revealed that annual $\mathrm{N}$ application is not essential to produce a good crop. Molina-Soria and Fernández-Escobar (2010) suggested that the leaf $\mathrm{N}$ deficiency threshold for mature olives trees range from $1.22 \%$ to $1.35 \% \mathrm{~N}$ (\% leaf dry matter), whereas the toxicity $\mathrm{N}$ threshold level is greater than $1.7 \% \mathrm{~N}$. In our study, leaf $\mathrm{N} \%$ was never below $1.2 \%$ for all $\mathrm{N}$ sources (AN, CN, and OSC) and levels (2.8 and $5.6 \mathrm{~g} /$ tree $\mathrm{N})$, except for the lower level of OSC (1.16\%) in 2016 (Table 3). High leaf $\mathrm{N}$ concentration specifically, during the first year of 2015, could explain the nonsignificant effect of the higher $\mathrm{N}$ level $(5.6 \mathrm{~g} /$ tree $\mathrm{N})$ treatment compared with the lower level ( $2.8 \mathrm{~g} /$ tree N). Given that shoot morphology and physiology was similar under high and low $\mathrm{N}$ levels and that leaf

Table 2. Plant morphology (plant height, stem diameter, total branches number, total leaf area, and total fresh and dry weight) and physiology [photosynthesis $\left(\mathrm{P}_{\mathrm{n}}\right)$; stomatal conductance $\left(g_{\mathrm{s}}\right)$; and transpiration $(E)$ ] of olive transplants grown under different N-source and levels for two growing seasons; 2015 and 2016.

\begin{tabular}{|c|c|c|c|c|c|c|c|c|c|c|c|}
\hline Yr & & Treatments & $\begin{array}{c}\text { Plant } \\
\text { ht }(\mathrm{cm})\end{array}$ & $\begin{array}{c}\text { Stem } \\
\operatorname{diam}(\mathrm{mm})\end{array}$ & Branch no. & $\begin{array}{c}\text { Leaf } \\
\text { area }\left(\mathrm{cm}^{2}\right)\end{array}$ & $\begin{array}{c}\text { Leaf fresh } \\
\text { wt (g) }\end{array}$ & $\begin{array}{c}\text { Leaf dry } \\
\text { wt (g) }\end{array}$ & $\begin{array}{c}\mathrm{P}_{\mathrm{n}} \\
\left(\mu \mathrm{mol} \cdot \mathrm{m}^{-2} \cdot \mathrm{s}^{-1}\right)\end{array}$ & $\begin{array}{c}g_{\mathrm{s}} \\
\left(\mathrm{mol} \cdot \mathrm{m}^{-2} \cdot \mathrm{s}^{-1}\right)\end{array}$ & $\begin{array}{c}E \\
\left(\mathrm{mmol} \cdot \mathrm{m}^{-2} \cdot \mathrm{s}^{-1}\right) \\
\end{array}$ \\
\hline \multirow{6}{*}{$\overline{2015}$} & & Calcium nitrate & 118 & 11.2 & 53.6 & $2,109 \mathrm{~b}$ & $89.3 \mathrm{~b}$ & $40.9 \mathrm{~b}$ & $9.16 \mathrm{ab}$ & 0.08 & 2.79 \\
\hline & & Osmocote & 113 & 10.8 & 59.1 & $2,066 \mathrm{~b}$ & $84.3 \mathrm{~b}$ & $38.5 \mathrm{~b}$ & $9.46 \mathrm{a}$ & 0.09 & 3.07 \\
\hline & Level (L) & Control & $93 \mathrm{~b}$ & $8.4 \mathrm{~b}$ & $42.5 \mathrm{~b}$ & $737 \mathrm{~b}$ & $31.0 \mathrm{~b}$ & $13.5 \mathrm{~b}$ & $6.03 \mathrm{~b}$ & 0.08 & 2.47 \\
\hline & & $2.8 \mathrm{~g} /$ tree & $121 \mathrm{a}$ & $11.4 \mathrm{a}$ & $53.5 \mathrm{a}$ & $2,178 \mathrm{a}$ & $90.1 \mathrm{a}$ & $41.3 \mathrm{a}$ & $8.67 \mathrm{a}$ & 0.08 & 2.72 \\
\hline & & $5.6 \mathrm{~g} /$ tree & $112 \mathrm{a}$ & $10.7 \mathrm{a}$ & $59.4 \mathrm{a}$ & $2,226 \mathrm{a}$ & $91.3 \mathrm{a}$ & $41.8 \mathrm{a}$ & $9.14 \mathrm{a}$ & 0.09 & 3.07 \\
\hline & & $\mathrm{S} \times \mathrm{L}$ & 0.380 & 0.21 & 0.17 & 0.19 & 0.54 & 0.39 & 0.15 & 0.85 & 0.57 \\
\hline \multirow[t]{7}{*}{2016} & Source & & & & & & & & & & \\
\hline & & Ammonium nitrate & $127 \mathrm{ab}$ & $13.4 \mathrm{a}$ & 98.1 & $4,034 \mathrm{ab}$ & $195.9 \mathrm{ab}$ & $90.1 \mathrm{ab}$ & 12.80 & 0.11 & 2.57 \\
\hline & & Calcium nitrate & $131 \mathrm{a}$ & $13.3 \mathrm{a}$ & 105.1 & $4,205 \mathrm{a}$ & $210.0 \mathrm{a}$ & $99.4 \mathrm{a}$ & 12.35 & 0.10 & 2.39 \\
\hline & & Osmocote & $119 \mathrm{~b}$ & $12.3 \mathrm{~b}$ & 97.1 & $3,666 \mathrm{~b}$ & $175.0 \mathrm{~b}$ & $80.7 \mathrm{~b}$ & 13.16 & 0.11 & 2.66 \\
\hline & & Urea & $121 \mathrm{~b}$ & $12.4 \mathrm{~b}$ & 102.1 & $3,652 \mathrm{~b}$ & $178.4 \mathrm{~b}$ & $82.2 \mathrm{~b}$ & 12.50 & 0.11 & 2.54 \\
\hline & & $\mathrm{L}$ & $<0.0001$ & $<0.0001$ & $<0.0001$ & $<0.0001$ & $<0.0001$ & $<0.0001$ & 0.001 & 0.10 & 0.06 \\
\hline & & $\mathrm{S} \times \mathrm{L}$ & 0.32 & 0.37 & 0.05 & 0.08 & 0.09 & 0.07 & 0.06 & 0.31 & 0.18 \\
\hline
\end{tabular}

Values, in columns within each year, followed different letters are significantly different at $P<0.05$. 
Table 3. Leaf and root $\mathrm{N} \%$ and $\mathrm{NO}_{3} \%$ of olive cuttings grown under different $\mathrm{N}$-source and levels for two growing seasons; 2015 and 2016.

\begin{tabular}{|c|c|c|c|c|c|c|}
\hline \multirow[b]{2}{*}{$\mathrm{Yr}$} & & \multirow[b]{2}{*}{ Treatments } & \multicolumn{2}{|c|}{$\mathrm{N} \%$} & \multicolumn{2}{|c|}{$\mathrm{NO}_{3}-\mathrm{N} \%$} \\
\hline & & & Leaf & Root & Leaf & Root \\
\hline \multirow[t]{10}{*}{$\overline{2015}$} & Source $(\mathrm{S})$ & Ammonium nitrate & $2.61 \mathrm{a}$ & $1.49 \mathrm{a}$ & $0.025 \mathrm{ab}$ & $0.047 \mathrm{a}$ \\
\hline & & Calcium nitrate & $2.35 \mathrm{~b}$ & $1.31 \mathrm{~b}$ & $0.011 \mathrm{~b}$ & $0.031 \mathrm{~b}$ \\
\hline & & Osmocote & $2.22 \mathrm{~b}$ & $1.20 \mathrm{~b}$ & $0.038 \mathrm{a}$ & $0.034 \mathrm{ab}$ \\
\hline & & Urea & $2.62 \mathrm{a}$ & $1.31 \mathrm{~b}$ & $0.023 \mathrm{ab}$ & $0.038 \mathrm{ab}$ \\
\hline & Level (L) & Control & $1.36 \mathrm{c}$ & $0.79 \mathrm{c}$ & 0.015 & $0.008 \mathrm{~b}$ \\
\hline & & $2.8 \mathrm{~g} /$ tree & $2.36 \mathrm{~b}$ & $1.23 \mathrm{~b}$ & 0.024 & $0.030 \mathrm{a}$ \\
\hline & & $5.6 \mathrm{~g} /$ tree & $2.55 \mathrm{a}$ & $1.42 \mathrm{a}$ & 0.025 & $0.045 \mathrm{a}$ \\
\hline & $P$ value & S & $<0.0001$ & 0.03 & 0.03 & 0.05 \\
\hline & & $\mathrm{L}$ & $<0.0001$ & $<0.0001$ & 0.56 & 0.04 \\
\hline & & $\mathrm{S} \times \mathrm{L}$ & 0.08 & 0.08 & 0.13 & 0.31 \\
\hline \multirow[t]{10}{*}{2016} & Source & Ammonium nitrate & $1.70 \mathrm{a}$ & $1.31 \mathrm{a}$ & 0.025 & $0.023 \mathrm{~b}$ \\
\hline & & Calcium nitrate & $1.51 \mathrm{ab}$ & $1.21 \mathrm{a}$ & 0.011 & $0.041 \mathrm{a}$ \\
\hline & & Osmocote & $1.16 \mathrm{c}$ & $1.00 \mathrm{~b}$ & 0.038 & $0.010 \mathrm{bc}$ \\
\hline & & Urea & $1.47 \mathrm{~b}$ & $1.23 \mathrm{a}$ & 0.023 & $0.019 \mathrm{~b}$ \\
\hline & Level & Control & $0.71 \mathrm{c}$ & $0.74 \mathrm{c}$ & 0.015 & $0.003 \mathrm{~b}$ \\
\hline & & $2.8 \mathrm{~g} /$ tree & $1.34 \mathrm{~b}$ & $1.08 \mathrm{~b}$ & 0.024 & $0.018 \mathrm{a}$ \\
\hline & & $5.6 \mathrm{~g} /$ tree & $1.59 \mathrm{a}$ & $1.30 \mathrm{a}$ & 0.025 & $0.029 \mathrm{a}$ \\
\hline & $P$ value & $\mathrm{S}$ & 0.002 & $<0.0001$ & 0.28 & 0.001 \\
\hline & & $\mathrm{L}$ & 0.0001 & $<0.0001$ & 0.73 & 0.02 \\
\hline & & $\mathrm{S} \times \mathrm{L}$ & 0.06 & 0.22 & 0.59 & 0.59 \\
\hline
\end{tabular}

Values, in columns within each year, followed different letters are significantly different at $P<0.05$.

Table 4. Total root dry weight, length, surface area (RSA), diameter, volume, and fork number of olive cuttings grown under different $\mathrm{N}$-source and levels for two growing seasons; 2015 and 2016.

\begin{tabular}{|c|c|c|c|c|c|c|c|c|}
\hline \multirow[b]{2}{*}{$\mathrm{Yr}$} & & \multirow[b]{2}{*}{ Treatments } & \multicolumn{6}{|c|}{ Root components } \\
\hline & & & Dry wt $(\mathrm{g})$ & $\begin{array}{l}\text { Length } \\
(\mathrm{cm})\end{array}$ & $\begin{array}{l}\mathrm{RSA} \\
\left(\mathrm{cm}^{2}\right)\end{array}$ & $\operatorname{Diam}(\mathrm{mm})$ & $\begin{array}{c}\text { Volume } \\
\left(\mathrm{cm}^{3}\right)\end{array}$ & Fork (no.) \\
\hline \multirow[t]{10}{*}{$\overline{2015}$} & Source $(\mathrm{S})$ & Ammonium nitrate & 12.7 & $13,238 \mathrm{a}$ & $2,494 \mathrm{a}$ & $0.63 \mathrm{~b}$ & $38.7 \mathrm{a}$ & $3,936 \mathrm{a}$ \\
\hline & & Calcium nitrate & 12.4 & $9,426 \mathrm{bc}$ & $1,938 \mathrm{~b}$ & $0.67 \mathrm{a}$ & $32.6 \mathrm{~b}$ & $2,919 \mathrm{bc}$ \\
\hline & & Osmocote & 12.0 & $9,353 \mathrm{c}$ & $1,842 \mathrm{~b}$ & $0.65 \mathrm{ab}$ & $29.9 \mathrm{~b}$ & $2,309 \mathrm{c}$ \\
\hline & & Urea & 13.9 & $11,691 \mathrm{ab}$ & $2,215 \mathrm{ab}$ & $0.63 \mathrm{~b}$ & $34.5 \mathrm{ab}$ & $3,537 \mathrm{ab}$ \\
\hline & Level (L) & Control & $8.6 \mathrm{c}$ & $8,652 \mathrm{~b}$ & $1,689 \mathrm{~b}$ & $0.66 \mathrm{a}$ & $27.7 \mathrm{~b}$ & $2,085 \mathrm{~b}$ \\
\hline & & $2.8 \mathrm{~g} /$ tree & $14.2 \mathrm{a}$ & $10,126 \mathrm{ab}$ & $2,067 \mathrm{a}$ & $0.67 \mathrm{a}$ & $34.7 \mathrm{a}$ & $2,921 \mathrm{a}$ \\
\hline & & $5.6 \mathrm{~g} /$ tree & $11.3 \mathrm{~b}$ & $11,728 \mathrm{a}$ & $2,177 \mathrm{a}$ & $0.62 \mathrm{~b}$ & $33.1 \mathrm{a}$ & 3,429 a \\
\hline & $P$ value & $\mathrm{S}$ & 0.40 & 0.003 & 0.01 & 0.007 & 0.02 & 0.002 \\
\hline & & $\mathrm{L}$ & $<0.0001$ & 0.004 & 0.03 & $<0.0001$ & 0.07 & 0.005 \\
\hline & & $\mathrm{S} \times \mathrm{L}$ & 0.34 & 0.006 & 0.02 & 0.21 & 0.06 & 0.11 \\
\hline \multirow[t]{10}{*}{2016} & Source & Ammoni & 42.5 & $21,049 \mathrm{a}$ & $3,728 \mathrm{a}$ & 0 & 75.6 & $99 \mathrm{a}$ \\
\hline & & Calci & 40. & 20,4 & $3,635 \mathrm{ab}$ & 0 & 75 & $4 \mathrm{ab}$ \\
\hline & & Osmocote & $37.9 \mathrm{ab}$ & $19,677 \mathrm{ab}$ & $3,508 a b$ & 0.70 & 69.9 & $3,535 \mathrm{ab}$ \\
\hline & & Urea & $33.9 \mathrm{~b}$ & $18,482 \mathrm{~b}$ & $3,317 \mathrm{~b}$ & 0.66 & 69.4 & $3,296 \mathrm{~b}$ \\
\hline & Level & Control & $18.6 \mathrm{~b}$ & $13,892 \mathrm{~b}$ & $2,583 \mathrm{~b}$ & 0.69 & $55.7 \mathrm{~b}$ & $2,378 \mathrm{~b}$ \\
\hline & & $2.8 \mathrm{~g} /$ tree & $37.4 \mathrm{a}$ & $19,528 \mathrm{a}$ & $3,484 \mathrm{a}$ & 0.71 & $71.8 \mathrm{a}$ & $3,506 \mathrm{a}$ \\
\hline & & $5.6 \mathrm{~g} /$ tree & $40.0 \mathrm{a}$ & $20,310 \mathrm{a}$ & $3,610 \mathrm{a}$ & 0.66 & $73.3 \mathrm{a}$ & $3,662 \mathrm{a}$ \\
\hline & $P$ value & $\mathrm{S}$ & 0.04 & 0.05 & 0.04 & 0.39 & 0.15 & 0.05 \\
\hline & & $\mathrm{L}$ & $<0.0001$ & $<0.0001$ & $<0.0001$ & 0.16 & $<0.0001$ & 0.001 \\
\hline & & $\mathrm{S} \times \mathrm{L}$ & 0.001 & 0.001 & 0.001 & 0.88 & 0.002 & 0.01 \\
\hline
\end{tabular}

Values, in columns within each year, followed different letters are significantly different at $P<0.05$.

$\mathrm{N}$ in the lower $\mathrm{N}$ level was within the range, $2.8 \mathrm{~g} /$ tree $\mathrm{N}$ proved to be adequate to maintain a healthy and balanced growth in olive cuttings.

Root components. Root growth requires sufficient supply of nutrients from the soil and translocation of photosynthates from the shoot. Changes in $\mathrm{N}$ nutrient availability in the growing medium affects root-hair formation, primary root growth, and lateral root formation (Leskovar and Othman, 2016; López-Bucio et al., 2003). During the study period 2015-16, significant differences between fertilizer sources and rates were found (Table 4; Fig. 2). Ammonium nitrate and urea $\mathrm{N}$ fertilizer sources enhanced root components as compared with $\mathrm{CN}$ and OSC, espe-
Bucio et al., 2003; Takács and Técsi, 1992). For example, at a $3: 1 \mathrm{NO}_{3}{ }^{-} / \mathrm{NH}^{+}$ratio the surface area of the photosynthesizing membrane was higher than at $0: 1$ or $1: 3 \mathrm{NO}_{3}{ }^{-} /$ $\mathrm{NH}^{+}$ratio (Takács and Técsi, 1992). A homogeneous supply of $3: 1 \mathrm{NO}_{3}{ }^{-} / \mathrm{NH}^{+}$ratio to tomato transplants resulted in the maximum shoot and root dry matter, root surface area and root volume compared with 1:0, 0:1, or 1:1 $\mathrm{NO}_{3}{ }^{-} / \mathrm{NH}^{+}$ratios (Lu et al., 2009).

Nitrate and phosphate act as signals regulating root cell division and differentiation, with remarkable effect on the overall root system architecture (López-Bucio et al., 2003). Root $\mathrm{N}$ uptake is regulated locally by the concentration of $\mathrm{N}$ in the substrate and by a systemic feedback regulated by wholeplant signals of $\mathrm{N}$ status (Nacry et al., 2013). Excessive annual applications of $\mathrm{N}$ fertilizer may lead to toxic overdose of $\mathrm{N}$ and negative impacts on both the plant and the environment (Fernández-Escobar et al., 2014). Tsabarducas et al. (2017) found that $\mathrm{NH}_{4}{ }^{+}-\mathrm{N}$ at $225 \mathrm{mg} \cdot \mathrm{L}^{-1}$ resulted in lower net photosynthetic rate, total $\mathrm{Ca}^{+2}, \mathrm{Mg}^{+2}$, and higher $\mathrm{K}$ uptake compared with lower $\mathrm{N}$ levels. Given that most root components were statistically similar at both $\mathrm{N}$ levels, we believe that excessive amount of $\mathrm{N}$ such as the high level of $\mathrm{N}(5.6 \mathrm{~g} /$ tree $\mathrm{N})$ to olive transplants is unnecessary.

The N source and level treatment interactions revealed that root component (root volume, surface area, and root length) from control $(0 \mathrm{~g} /$ tree $\mathrm{N})$ plants was higher than 2.8 and $5.6 \mathrm{~g} /$ tree $\mathrm{N}$ rates of $\mathrm{AN}$ and OSC during the first growing season (2015) and significantly lower than both levels at the end of the experiment, July 2016. This is can be attributed to an adequate leaf $\mathrm{N}$ concentration in the untreated-control cuttings leaves during the first year $(1.3 \% \mathrm{~N})$ compared with the second year $(0.7 \% \mathrm{~N})$; which was below the $\mathrm{N}$ deficiency threshold (1.22\% to $1.35 \% \mathrm{~N}$ of dry weight) as suggested by Molina-Soria and Fernández-Escobar (2010) for mature trees. As external inputs of $\mathrm{NO}_{3}{ }^{-}$and $\mathrm{NH}_{4}{ }^{+}$ levels increased in agricultural soils, elevated rates of $\mathrm{NO}_{3}{ }^{-}$and $\mathrm{NH}_{4}{ }^{+}$efflux lower the capacity of roots to uptake external N; except $\mathrm{N}$-starved roots that have a high absorption capacity (Glass, 2003). The delivery of high $\mathrm{NH}_{4}{ }^{+}$concentration to plant roots actively absorbing $\mathrm{NO}_{3}{ }^{-}$reduces $\mathrm{NO}_{3}{ }^{-}$uptake and lowers the efficient utilization of soil $\mathrm{NO}_{3}{ }^{-}$ (Glass, 2003).

Slow-release fertilizers release nutrient to soil slower than conventional fertilizers and the duration of release depends on microbial activity that is driven by soil moisture and temperature conditions (Liu et al., 2017). Slow-release fertilizers have been recommended by environmentalist as an alternative to traditional fertilizer to reduce the toxic effect of excessive $\mathrm{N}$ lost by leaching (Fernández-Escobar et al., 2004; LópezBucio et al., 2003; Socolow, 1999). This could be attributed to the fact that slowrelease fertilizer can reduce nutrient losses and increase nutrient-use efficiency (Liu et al., 2017). It has been reported that the total $\mathrm{N}$ losses from slow-release fertilizers 


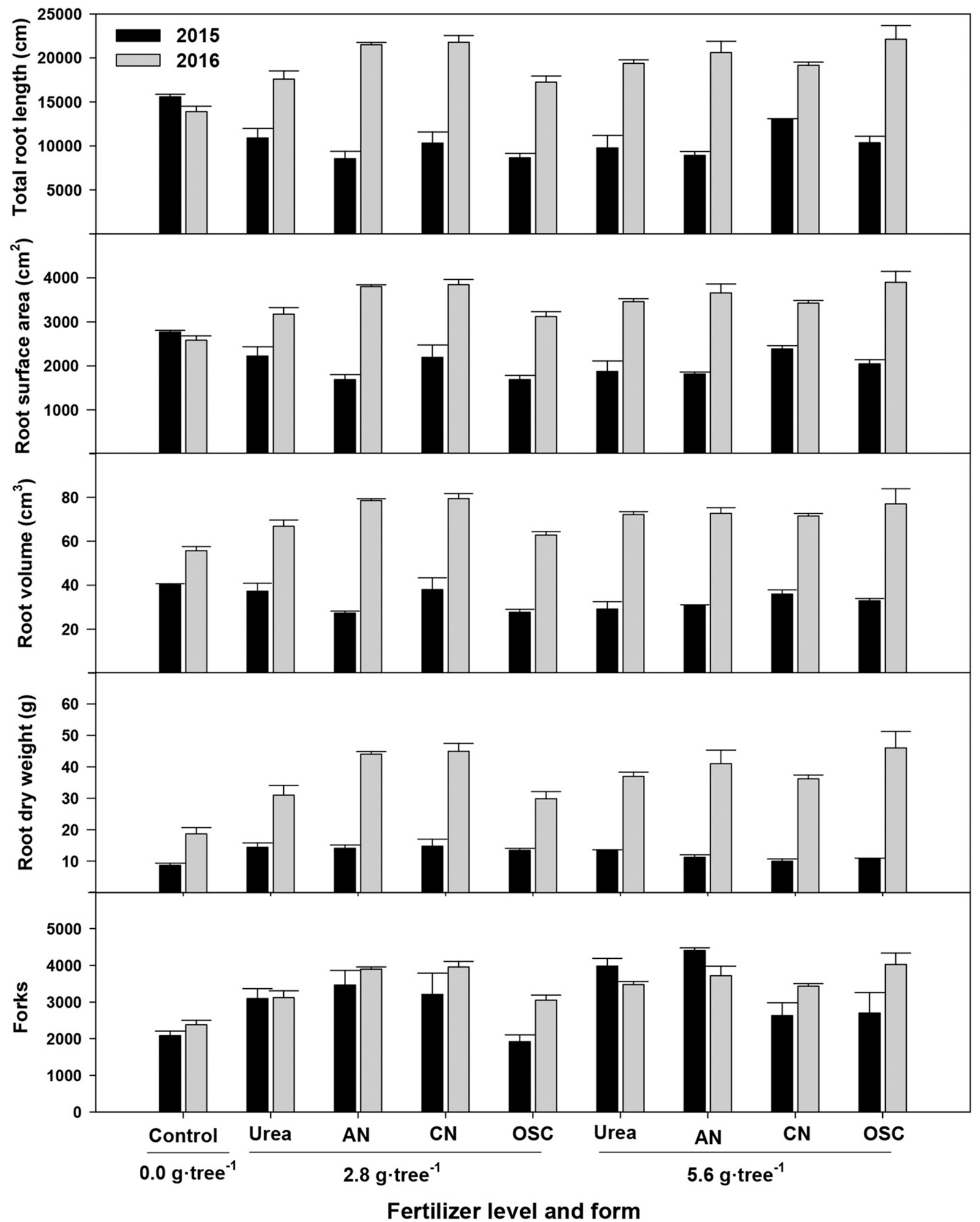

Fig. 2. Total root length, surface area, volume, total root dry weight, and total fork number of olive cuttings grown under different N-sources and levels for two growing seasons; 2015 and 2016. $\mathrm{AN}=$ ammonium nitrate; $\mathrm{CN}=$ calcium nitrate; OSC $=$ slow-release Osmocote.

are lower than traditional fertilizers such as, the controlled-released fertilizer (OSC) AN and CN (Fernández-Escobar et al., 2004). levels was different from other studied sourIn this study, the response of olive cuttings to ces (urea, AN, CN). Although cuttings that received a lower rate $(2.8 \mathrm{~g} /$ tree $\mathrm{N})$ of $\mathrm{AN}$ $\mathrm{CN}$ and urea showed similar or better growth response than the higher rate $(5.6 \mathrm{~g} /$ tree $\mathrm{N})$, 
olive cuttings that received a higher rate of OSC had better root growth than those treated with the lower rate (Fig. 2). FernándezEscobar et al. (2004) found that olive 'Picual' seedling fertilized using traditional and slowrelease $\mathrm{N}$ fertilizers exhibited similar growth rate at a low $\mathrm{N}$ rate $(0.75 \mathrm{~g} /$ tree $\mathrm{N})$ but greater shoot growth was obtained with slow-release $\mathrm{N}$ fertilizers when higher level $(2.0 \mathrm{~g} /$ tree $\mathrm{N})$ of fertilizer was applied.

\section{Conclusions}

In this study we found that olive young trees that received $2.8 \mathrm{~g} /$ tree $\mathrm{N}$ rate had similar plant morphology (plant height, diameter, branch number, leaf area, and fresh weight) and gas exchange $\left(\mathrm{P}_{\mathrm{n}}, g_{\mathrm{s}}\right.$ and $\left.E\right)$ compared with those that receive $5.6 \mathrm{~g} /$ tree $\mathrm{N}$. However, plant morphology and gas exchange was significantly reduced in the absence of $\mathrm{N}$ fertilizer (control). Nitrogen source had a significant effect on olive shoot and root morphology, physiology and leaf and root $\mathrm{N}$ concentration. It was clear that $\mathrm{CN}$ $(2.8 \mathrm{~g} /$ tree N$)$ was the best in terms of growth of the aerial part and never worse than $\mathrm{AN}$ in terms of root growth and structure at the end of the experimental period. Root components treated with high $\mathrm{N}$ rate $(5.6 \mathrm{~g} /$ tree $\mathrm{N})$ using the slow-release fertilizer (OSC) was similar to those treated with the low AN rate $(2.8 \mathrm{~g} /$ tree N). Therefore, for nursery containerized olive trees of 'Arbequina' or other cultivars with comparable growth rates, we recommend to apply the $\mathrm{CN}$ or AN source at $2.8 \mathrm{~g}$ / tree $\mathrm{N}$ or the controlled-released fertilizer OSC at $5.6 \mathrm{~g} /$ tree $\mathrm{N}$.

\section{Literature Cited}

Al-Ajlouni, M., J. Ayad, and Y. Othman. 2017. Increasing nutrient levels promote growth and flower quality in lilies grown under soilless culture. Hort. Sci. (Prague) 44:213-219.

Andrews, M. 1986. The partitioning of nitrate assimilation between root and shoot of higher plants. Plant Cell Environ. 9:511-519.

Bouranis, D., C. Kitsaki, and A. Tzakosta. 2004. Differences in nitrate and ammonium homeostasis of reproductive and vegetative shoots of olive tree cv. Kalamon during inflorescence development. J. Plant Nutr. 27(5):797-813.

Boussadia, O., K. Steppe, M. Van Labeke, R. Lemeur, and M. Braham. 2015. Effects of nitrogen deficiency on leaf chlorophyll fluorescence parameters in two olive tree cultivars 'Meski' and 'Koroneiki'. J. Plant Nutr. 38(14):22302246.

Boussadia, O., K. Steppe, H. Zgallai, S. El Hadj, M. Braham, R. Lemeur, and M. Van Labeke. 2010. Effects of nitrogen deficiency on leaf photosynthesis, carbohydrate status and biomass production in two olive cultivars 'Meski' and 'Koroneiki'. Scientia Hort. 123:336-342.

Connell, J., L. Ferguson, P. Metheney, H. Reyes, W. Krueger, and G. Sibbett. 2002. Effects of foliar application of urea on olive leaf nitrogen, growth, and yield. Acta Hort. 586:251-254.

Fernández-Escobar, R., M. Antonaya-Baena, M. Sánchez-Zamora, and C. Molina-Soria. 2014. The amount of nitrogen applied and nutritional status of olive plants affect nitrogen uptake efficiency. Scientia Hort. 167:1-4.

Fernández-Escobar, R., M. Benlloch, E. Herrera, and J. Garcia-Novelo. 2004. Effect of traditional and slow-release $\mathrm{N}$ fertilizers on growth of olive nursery plants and $\mathrm{N}$ losses by leaching. Scientia Hort. 101:39-49.

Fernández-Escobar, R., J. García-Novelo, C. Molina-Spria, and M. Parra. 2012. An approach to nitrogen balance in olive orchards. Scientia Hort. 135:219-226.

Glass, A. 2003. Nitrogen use efficiency of crop plants: Physiological constraints upon nitrogen absorption. Crit. Rev. Plant Sci. 22(5):453-470.

Kiba, T., T. Kudo, M. Kojima, and H. Sakakibara. 2011. Hormonal control of nitrogen acquisition: Roles of auxin, abscisic acid, and cytokinin. J. Expt. Bot. 62(4):1399-1409.

Leskovar, D. and Y. Othman. 2016. Low nitrogen fertigation promotes root development and transplant quality in globe artichoke. HortScience 51:567-572.

Liu, G., L. Zotarelli, Y. Li, D. Dinkins, Q. Wang, and M. Ozores-Hampton. 2017. Controlledrelease and slow-release fertilizers as nutrient management tools. HS1255. Univ. Florida/ IFAS Ext.

López-Bucio, J., A. Cruz-Ramírez, and L. HerreraEstrella. 2003. The role of nutrient availability in regulation root architecture. Curr. Opin. Plant Biol. 6:280-287.

Lu, Y., Y. Xu, Q. Shen, and C. Dong. 2009. Effects of different nitrogen forms on the growth and cytokinin content in xylem sap of tomato
(Lycopersicon esculentum Mill.) seedlings. Plant Soil 315:67-77.

Molina-Soria, C. and R. Fernández-Escobar. 2010. The reliability of the established critical leaf nitrogen concentration in olive orchards. Acta Hort. 868:209-212.

Nacry, P., E. Bouguyon, and A. Gojon. 2013. Nitrogen acquisition by roots: Physiological and developmental mechanisms ensuring plant adaptation to a fluctuating resource. Plant Soil 370:1-29.

Othman, Y., D. VanLeeuwen, R. Heerema, and R. St. Hilaire. 2014. Midday stem water potential values needed to maintain photosynthesis and gas exchange established for pecans. J. Amer. Soc. Hort. Sci. 139:537-546.

Rodrigues, M., I. Ferreira, M. Claro, and M. Arrobas. 2012. Fertilizer recommendations for olive based upon nutrients removed in crop and pruning. Scientia Hort. 142:205-211.

Rodrigues, M., J. Lopes, F. Pavão, J. Cabanas, and M. Arrobas. 2011a. Effect of soil management on olive yield and nutritional status of trees in rainfed orchards. Commun. Soil Sci. Plant Anal. 42(9):993-1007.

Rodrigues, M., F. Pavão, J. Lopes, V. Gomes, M. Arrobas, J. Moutinho-Pereira, S. Ruivo, J. Cabanas, and C. Correia. 2011b. Olive yields and tree nutritional status during a four-year period without nitrogen and boron fertilization. Commun. Soil Sci. Plant Anal. 42(7):803-814.

Saidana, D., M. Braham, D. Boujnah, F. Ben Mariem, S. Ammari, and S. Ben El Hadj. 2009. Nutrient stress, ecophysiological, and metabolic aspects of olive tree cultivars. J. Plant Nutr. 32:129-145.

Socolow, R. 1999. Nitrogen management and the future of food: Lessons from the management of energy and carbon. Proc. Natl. Acad. Sci. USA 96:6001-6008.

Takács, E. and L. Técsi. 1992. Effects of $\mathrm{NO}_{3}{ }^{-}$ $\mathrm{NH}_{4}^{+}$ratio on photosynthetic rate, nitrate reductase activity and chloroplast ultrastructure in three cultivars of red pepper (Capsicum annuum L.). J. Plant Physiol. 140:298-305.

Troyanos, Y. and E. Roukounaki. 2011. Response of young olive trees to nitrogen fertilization. Hell. Plant Protection J. 4:13-19.

Tsabarducas, V., T. Chatzistathis, I. Therios, and A. Patakas. 2017. How nitrogen form and concentration affect growth, nutrient accumulation and photosynthetic performance of Olea europaea L. (cv. 'Kalamon'). Scientia Hort. 218:23-29. 